\title{
THE CONCEPT OF "WAR" IN RUSSIAN LITERATURE OF THE TWENTIETH CENTURY
}

\author{
Olga Evdokimova ${ }^{1}$, Irina K. Ivanova ${ }^{2 \star}$, Larisa Lyapaeva ${ }^{3}$, Nataliia Obzhogina ${ }^{4}$, \\ Lyudmila Sarbash ${ }^{5}$, Svetlana Fedyay ${ }^{6}$ \\ ${ }^{1}$ Assoc. Prof., Chuvash State University, RUSSIA, evdokimova.ok@mail.ru \\ ${ }^{2}$ Assoc. Prof., Chuvash State University, RUSSIA, leocon2@yandex.ru \\ ${ }^{3}$ Assoc. Prof., Chuvash State University, RUSSIA, lar.lyapaeva@yandex.ru \\ ${ }^{4}$ Sen. Lect., Chuvash State University, RUSSIA, obnatur@gmail.com \\ ${ }^{5}$ Prof. Dr., Chuvash State University, RUSSIA, sarbash.lu@yandex.ru \\ ${ }^{6}$ Assoc. Prof., Chuvash State University, RUSSIA, sfedyaj09@mail.ru \\ ${ }^{*}$ Corresponding Author
}

\begin{abstract}
In this article, from the standpoint of studying the value paradigm of literature as one of the most striking forms of art that affect the consciousness and soul of man, the spiritual and moral problems of domestic prose devoted to the theme of war are considered. On the example of creativity of writers of the XX century B. Lavrenev (1891-1960), M. Sholokhov (1905 - 1984), Yu.Buida (b. in 1954), G. Yahinoy (b. in 1977) analyzes the figurative-symbolic and moral-philosophical content of the concept of "war", which allows to reveal one of the main tragedies of the XX century not as an ideological conflict of the warring parties, but as a conflict in the human soul. In this regard, the article touches upon the problem of traditions and innovations in the depiction of the war itself and man in the dramatic circumstances of the war in Russian classical literature. Based on the concept of concept, the authors show that the chronotope of war is not limited to historical events, but includes, first of all, human consciousness, regardless of its nationality. The binary structure of the world, created by war, unwittingly leads to a confrontation between "their" and "others". In the article on the example of works of different genres (novel, tale, short story) and different periods of the XX century the features of the image of the inner nature of a person, a person with his complex inner world caused by the events of the war are investigated. In the course of the analysis, the authors emphasize that the conflict caused by war in the soul and consciousness continues to live in man after the end of the war, defining his life within the framework of existential concepts or existence at the level of animal primitivism. The work builds a lexical synonymous series, which allows to show the commonality and differences in the understanding and attitude to the war as a human tragedy in Russian prose.
\end{abstract}

Keywords: Russian artistic prose of the XX - beginning of the XXI century, concept, war, man, "one's own" and "another's".

\section{INTRODUCTION}

The theme of the war in Russian literature of the 20th century is constant, which has become partly the "face" of Russian literature, a kind of tuning fork, according to which the purity of sounding of each work individually is verified. This topic is closely intertwined with a number of other topics that reveal the history of the country, but not only its victories, but also pain points. In the era of revolution and Civil War, collectivization and dispossession, of Stalinist terror, it was not easy to keep a person in it. The Great Patriotic War aggravated the "friends or foes" problem, took it beyond the limits of only ideological confrontation, indicating the depth of the contradictions caused by the war already in the post-war period. The relevance of this article is determined, first of all, by the fact that over the years the severity of the 
problem of war not only does not wane, but, on the contrary, becomes more and more tangible, while the problem itself takes on more and more facets a sense of guilt before those who have not returned from the war, historical memory, the problem of the non-ethnic in the war and in the post-war period. The literature constantly returns to the theme of war, to the multidimensionality of this issue, including the tragedy of the civil war, human behaviour on the battlefield, heroism and betrayal, all the hardships of life in occupied territory and in the rear, camps, the fate of prisoners of war and convicted by the Soviet government, and most importantly the consequences of war in the mind and soul of man. The aim of the undertaken study is to show how writers of different generations throughout the 20th century and the turn of the 20th-21st centuries depict not only and not so much the wars themselves, but the eternal struggle of Good and Evil, which, acquiring different forms, penetrates the human mind, perverts moral categories, violates the existential course of life.

\section{METHODOLOGY}

A theoretical analysis of the scientific literature on the topic of the article allowed us to determine the methodological foundations and conceptual ideas of the study. The focus is on the concept of "war", which makes it possible to reveal one of the most complex and ambiguous in its interpretation problems of literature of the 20th century the problem of war and its consequences in human life.

The method of analogy and a systematic approach were used at the stage of studying the work of Russian writers of both $1 / 2$ of the 20th century and the turn of the 20-21st centuries, followed by a synthesis of the author's position. Thus, thanks to a systematic approach, the most general patterns in understanding war as the greatest human tragedy and a deep spiritual and moral problem that did not disappear with the end of hostilities were revealed.

The principles of the synergistic approach, according to which complex open systems are considered selforganizing, are used to study the evolution of the concept of "war" in the literature of the XX - early XXI centuries. Any concept, as a rule, has several meanings since the author seeks to express not only his idea of the world around him, but also relies on a generally accepted system of values that reflect cultural traditions and national mentality (Fomenko, 2004). In fact, the concept is the result of a collision of the vocabulary of a word with a person's personal and folk experience (Likhachev, 1997). In this regard, the linguoculturological aspect is one of the vectors in the study of the concept, this direction becomes especially relevant when different national cultural traditions are in the spotlight, when the opposition "one's own" and "another's" appears in a work of art (Babenko, 2004; Romanova, Fedorova, 2017).

In literary criticism, the term "concept" is understood to mean content that, reflected in a certain type of consciousness of the writer, is realized in the semantic-associative context of a literary work (Baskakova, 2009; Gavrilova, 2010; Evdokimova, Lyapaeva, Fedyay, 2018).

Using empirical methods, in particular observation, the results are obtained that can be presented in the form of materials for practical and seminar classes in the subject "Actual problems of modern literary criticism", special courses on the history of Russian literature of the XX - XXI centuries, final qualification work of students, as well as circle works on contemporary Russian literature both with Russian-speaking students and with foreign students.

The material and methods of research are determined by the goal of showing the features of the functioning of the concept of "war" in Russian literature throughout the 20th century and the turn of the 20th $-21 \mathrm{st}$ centuries.

\section{RESULTS AND DISCUSSION}

The twentieth century, rich in a variety of events that determined the fate of people and the world has been vividly and comprehensively reflected in Russian literature. However, the tragedy of the war, incomparable with anything, occupies a special place in it and constantly attracts the attention of writers of different generations. Over time, ideological emphasis in the interpretation of this topic changed, but the interest in man in the war remained unchanged. It is from this point of view that the figurative-symbolic and moralphilosophical content of the concept of "war" is analysed, which allows revealing one of the main tragedies of the 20th century.

At the origins of the concept of "war" in Russian literature is the work of writers $1 / 2$ of the 20th century - I. Babel, M. Bulgakov, A. Vesely, B. Lavrenev, B. Pasternak, B. Pilnyak, A. Fadeev, M. Sholokhov, among which we highlight the names of Boris Andreevich Lavrenev (1891-1960) and Mikhail Alexandrovich Sholokhov (1905-1984). The works of these authors unite the view of war as an evil created in the world and in man in the first years after the revolution and the Civil War. In relatively small genre forms, prose writers 
sought to recreate "the enormous scale of events and the unusual relationship of man and history" (Skorospelova, 2003, p. 11). It is characteristic that both writers comprehend what is happening from the standpoint of Eternity. Artists depict a terrible age, a time of war, when moral categories are perverted as a result of post-revolutionary civil confrontation. The focus of both B. Lavrenev and M. Sholokhov is not so much the war as the eternal struggle of Good and Evil explored through the prism of the events of the war. Representing the Civil War, writers seek to understand the changes in the consciousness and behaviour of participants in these events, which is reflected in the style of prose and in the symbolism of works, and they try to reveal the highest, ontological meaning behind the cruelties and losses of the era.

The works of B. Lavrenev and M. Sholokhov, dedicated to the events of the Civil War, are distinguished by the desire for deep generalization, the study of the social and cultural causes of civil confrontation, the semantic characteristics of the "red" and "white", "their" and "strangers", the image in the tragic conflict between personal and social, revolutionary duty and the moral law of deep human experience.

Indicative in this respect was the story of B.A. Lavrenev "Forty-first" (1924), based on the plot of which is love that suddenly broke out between the captive White Guard officer Govorukha-Otrok and the shooter of the Red Army Marutka, who were on an uninhabited island in the Aral Sea. The author combines the romantic and ironic stylistics of presentation, playing up the plot of love for an educated nobleman, officer and commoner with all their cultural and philosophical differences, and the almost biblical situation of "heavenly bliss" of two lovers, separated from the rest of the world, each remaining adherent of his truth about peace and revolution. "An indefatigable craving for a lieutenant, for his thin hands, for a quiet voice, and most of all for the eyes of an unusual blue, grew in Marutkin's heart. From her, from blue, life brightened" (Lavrenev, 1982 , p. 59). And it turned out that this feeling is able to squeeze out the bitterness and class hatred from the heart. The tragic ending, in which Marutka shot her beloved and cries about what she did, testifies not only to the "psychology of the story" (Sukhikh, 2013, p. 55), but also to the extent of national disunity, the fierce confrontation between the consciousness of a private person and the generally accepted ideology. The author of the story pursues the idea of the value of personality, human personality, debunking the absolutization of class and political priorities.

In contrast, B. Lavrenev, M. Sholokhov finds his own approach to depicting the events of the Civil War: the concept of "war" in "Tales of the Don" (1924-1926) is revealed through the prism of family relations, the eternal problem of "fathers and children". Such a view gives the author the opportunity to emphasize, focusing on this aspect of the problem, to uncover the tragedy of civil strife, where on the one hand there are old Cossacks holding onto the former order, and on the other, young people who uphold the ideals of a new social truth (Wormhole, Kolovert, "Azure steppe", "Mole"). The author shows the destruction of centuries-old patriarchal relations, which testifies to the fundamental changes in the popular consciousness ("Birthmark", "Family Man", etc.). So, Mikishara from the story "Family Man" is trying to justify himself by killing two sons to honour the elders for breaking his father's covenant, which is an immutable law for the Cossack world. A completely different situation in the story "Birthmark", whose hero remains faithful to the Cossack traditions. Having recognized his own son in the Red Army killed by him, he himself puts himself to death.

The motives of the worldview shift, the destruction of the principles of continuity of generations are complemented by motives of love and reconciliation ("Shibalok's Family", "Foal", "Alien Blood"). So, Yakov Shibalok ("Shibalok's Family"), despite the conflicting opinions of his comrades in arms, saves the life of a newborn son born from a connection with the "ideological enemy": "We have half the participants in it, my seed is it, and let it live stays. You have wives and children, but I, besides him, have no one ..." (Sholokhov, 1986 , p. 230). Blood relations for the hero became more important than ideological confrontation. So, thanks to the image of the child, the reader does not have a "sensation of the meaninglessness of being" (Khvatov, 1978, p. 134). It is characteristic that faith in immortality and the triumph of life distinguishes all the works of M.A. Sholokhov.

In «Tales of the Don», M. Sholokhov exposes the conflict of social and universal positions, but at the same time invariably demonstrates adherence to timeless moral values. It is no coincidence that the writer chose the story "Alien Blood" as a generalizing ending for the entire cycle. On the one hand, it is an ideologically seasoned story written in the spirit of the Soviet era. So, the main character Gavril, whose son served and died in the ranks of the White Army, nurses the wounded foodstuffer Mikhail, experiencing quite paternal feelings for the young man: "Although someone else's blood in you, but in the soul I worry about you, as for my own..." (Sholokhov, 1986, p. 495). On the other hand, in the image of Gavril Sholokhov showed the best aspects of the patriarchal Cossacks: compassion, sympathy, willingness, regardless of views, to accept a person in need of help as his own. And Mikhail, in turn, not renouncing his principles, is grateful to the old people, trying to help them with the housework, and respond kindly to kindness. He albeit briefly is included in the paradigm of family-kinship relations, which, according to the author, are more important than social and philosophical differences. As a result, "Tales of the Don" is a narrative about the destruction of the 
former world order, about the crisis of life, the overcoming of which the author sees in addressing the original categories of good and mutual understanding.

Thus, in the works of B. Lavrenev and M. Sholokhov, depicting the tragedy of the Civil War, the concept of "war" is associated primarily with universal ideas about humanism. In their works, these authors showed a grandiose clash of two ideologies that brought a person to the brink of death, but he found the strength to rise above ideological differences and be just a person who is guided, above all, by the principles of universal morality.

The work of Yuri Buida (born in 1954) is a chronologically new stage in the depiction of war. The writer, born 9 years after the end of World War II in the territory that was left to the Soviet Union as the victorious country, the Kaliningrad region, creates a series of stories in which the immigrants of these lands are in the spotlight (Buida, 2015). It is no coincidence that in his works the author addresses the difficult fate of his native land, depicting the events of the war from a somewhat unexpected point of view for Russian prose about the war (Ivanova, 2016). Thus, in the collection of short stories "The Prussian Bride", created in the 1990s, Yu. Buida shows that the creation of a new story began with the settlement of land alien and hostile to immigrants (Spivak, 2004). A special "Prussian chronotope" of stories incorporates different time layers - both pre-war, and military, and post-war, and the concept of "war" is filled with biblical meaning. In stories such as "Alien Bone" and "Eve Eve", the fate of the heroes, correlated with the eternal stories of love, involuntarily leads the reader to think about eternal values, and the scene in the image of the author becomes almost sacred. Thus, thanks to the works of Yu. Buida, the content of the concept of "war" strengthens the Christian context, which, paradoxically as a whole, is characteristic of this concept, deepening the idea of humanism in war conditions as one of the main categories of life.

The new generation of writers, who did not know the war, but for whom the historical memory of the war and its consequences are the spiritual and moral foundations of modern society, finds its angle and its creative space in understanding the war at the turn of the 20th - 21st centuries. One of the most prominent representatives of this generation is Guzel Yakhina (born in 1977), a Tatar Russian-speaking writer who, in her works, addressing the events of the 20-40s of the 20th century, caused by the Civil War, collectivization and its consequences, touches the problem of the foreign. This problem, despite its relative novelty in literary criticism, has already become the subject of reflection in various aspects (Sarbash, 2012), but this problem has not yet been considered in interaction with the events of the war.

Guzel Yakhina, relying on literary traditions, takes a new approach to understanding the problems of war. The existential borderline situation of a person "condemned to be free" (Sartre, 1990, p. 327) in his choice, bearing responsibility for him, was quite often realized in military prose (V. Astafyev, V. Bykov, D. Granin, V. Rasputin, A. Camus, G. Grass, G. Belle, M. Zusak). So, V. Bykov, a Belarusian front-line writer, expressed the essence of the conflict of personality and time in the novel "In the Fog" (1987): "I want to live, and I want to stay a person. But how?" (Bykov, 1987, p. 36). V. Grossman, Ch. Aitmatov and a number of other prose writers transfer this issue to the relationship between man and the state. G. Yakhina, following the principles of "anxiety", "despair" of existentialism, also puts the heroes in a situation of moral experiment, revealing the possibilities of the human spirit, and like V. Bykov and V. Grossman, demonstrates their infinity.

The story "Rifle" (2014), in which G. Yakhina depicts a clear, open war: fights, a house passing from Germans to Russians and back several times a day, eighteen-year-old nurse Maya, who rescues fighters mechanically, almost without emotions for which there is neither strength nor time. The author shows us part of her day, sparingly describing her appearance and focusing on the girl dragging a rifle out of a bloody funnel - the remains of an unidentified soldier, another victim of the war, on the blood of many wounded on her sister's bag. She saved 14 fighters that day. The smells of burning, urine, corpses, blood, the sounds of exploding bombs, groans of the wounded, bright or faded light from the windows, the sensation of a chest preventing crawling up the stairs - all this underlines the condition of a person who must crush his reflection in order to fulfil the main task: to get there to the wounded, to overcome the path under bullets, and so many times in a circle. "The man at the front should be like a rifle. It is necessary - it shoots. No need - waiting for when it will be necessary" (Yakhina, 2015, p. 73).

However, it's completely impossible to crush feelings, to understand what is happening - already on the first floor of the house Maya, seeing a dead German, thinks about whether she could save a sweaty and dirty enemy, just like her own, or ignore his moans, or maybe finish off would be a fascist. This idea is the essence of the problem that life and war will pose before it after half an hour and which will have to be solved with lightning speed.

As in the stories of V. Bykov, the "Rifle" by G. Yakhina shows the everyday feat of a simple fighter against the backdrop of a confrontation between "friends" and "strangers". The composition of the story is built as 
Maya's climb to the fifth floor of the house, to the wounded soldiers who remained here after the territory was surrendered to the enemies, a clash with the Germans and the return of the nurse with the wounded, but not his own - a stranger. Maya is ready to hide if there are too many fascists, and she is ready to fight if she is alone with the Fritz, although she has not yet killed a single enemy. Only when Maya shoots the enemy, she sees in front of her not a fascist, but a teenager who is no more than fourteen years old, professionally evaluates his wound as serious, requiring surgery.

The author intersperses the thoughts and physical sensations of the heroine of the story: "How could I not make out?" And if I could make out - what, wouldn't I shoot? Of course I would. Or is he in me. And now finish off? So, looking down at the face? A cold stream flows along the spine" (Yakhina, 2015, p. 76). G. Yakhina very specifically describes the situation of the young heroine's choice of the story, once again confirming the thesis of existentialism that "a person is not completed like a thing and makes himself out of what he is: a conscientious or a scoundrel, a defender or a traitor, a hero or a coward" (Khusainova, 2015, p. 92).

A German soldier and a Russian nurse speak different languages, but intuitively understand each other. Eighteen and fourteen years is the dawn of life, doomed to fade away in a meat grinder of war. The "friend or foe" situation puts Maya in an existential situation: to finish off the enemy or save a person, almost a child, "a green dogface" (Yakhina, 2015, p. 77). The hero's remark about the girl's hair, so similar to his mother's hair, the impressionistly ragged facial features of Augustus Romm (so-called himself wounded), emphasizing his beauty and youth, make Maya's soul almost completely coarse from the constant encounter with death open up, recalling humanity. G. Yakhina briefly, but vividly describes the stages of this awakening: finish off, indifferently go through to get to your own, or linger; make a dressing and throw it on the balcony or drag yourself into the medical battalion of this fifteenth; save yourself or your enemy. Everything is decided by the seconds and the request for help from Romm, understandable without translation. The descent down the stairs is described in as much detail as the climb along it. The author of the story, along with Maya, notes the lightness of Augustus's body, the shots that prevent the corpses from walking, the sight of a weakening wounded man, who eventually has to be carried on his shoulders.

The heavy male work performed by a fragile girl (her low weight is emphasized by the writer at the beginning of the story), again and again returns to the idea that "the war does not have a female face", but it is women who act in difficult times, first of all, at the behest of the heart because they cannot do otherwise. Each floor is a new frontier, a new microresolution to the sounds of gunfire: to go further or to abandon the seriously wounded, but each time Maya only gets angry that Augustus is not saving energy, uttering a phrase after phrase in a weakening voice, not thinking about survival. Each floor is also a new stage of Maya's spiritual ascent: after leaving the balcony, she never thinks of the German as an enemy, only as a boy in need of help. "Sister" works for life, not death, therefore, peacetime references are interwoven into the chronology of their relationship: "His skin smells of powder smoke, and even barely audible - coffee with milk. Maya remembers this smell well: they were always given on Wednesdays at school" (Yakhina, 2015, p. 77).

The common path of former enemies is interrupted when the Nazis again seize the house. Saving people in war is often doomed to failure. Maya only regrets the rifle left hanging on the stairs. At first, before the bombing, it was a regret for the thing that accompanied the nurse all day as a comrade. Then, after the destruction of the street, the Germans, including Augustus, are a symbolic pendulum of the war, which divided into two halves of people who, it would seem, have nothing to divide. Augustus tells Maya on one of the turns of the stairs: "I had three brothers. All died in the war" (Yakhina, 2015, p. 78). So in the story of G. Yakhina, a rifle as a symbol of death reminds the reader not only about the victims of the battles, but also about the threat to the future of the common world.

In the novel "Zuleikha Opens Her Eyes" (2015), the concept of "war" is not the main one, nevertheless it incorporates serious problems - the confrontation of power and man, the inhumanization and preservation of personality, despite repression, the fight against the enemy. The Great Patriotic War is invisibly present in the novel, indirectly influencing the fate of heroes, exiled settlers living in the village of Semruk on the Angara. The fate of the Tatars of Zuleikha, who lost her home and husband and ended up in exile in Siberia, illustrates the friendship of a woman with repressed "Leningraders" that was waged by the Soviet government in the 30 s and 40 s of the 20th century against all people living in the country (only in the village people of 21 nationalities gather). The theme of national stereotypes, relations between representatives of different nations has repeatedly been raised in Russian and foreign literature, for example, in the works of G. James (Obzhogina, 2007). G. Yakhina in the novel explains that the enmity between the Russians representatives of the Soviet government, and dispossessed Tatars has an exclusively political character. In Semruk, people of different nationalities and religions get along peacefully because everyone was in an equally disenfranchised position. 
The war is also among those who control the "enemies of the people": state security lieutenant Zinovy Kuznets, making a career on people's lives, imitating him Vasily Gorelov, ready to betray everyone and everything, not knowing humanity, and Ivan Ignatov, the commandant of Semruk - a tough man, sometimes cruel, but deeply moral, fair, suffering from the role that the party and the Blacksmith imposed on him. The inhabitants of the village feel a double attitude towards him: they both hate and understand. Ivan Ignatov "was the one who met them here, at the end of the world. He drove into the taiga, starved with overwork, squeezed the plan with an iron hand, mocked, frightened, betrayed punishment. He built houses for them, fed them, knocked out food supplies and medicines, and protected them from the centre. Kept afloat. And they - held him" (Yakhina, 2018, p. 495).

Ivan Ignatov is suffering not only because of his semi-forced reference by the commandant to the Angara, but also because he cannot save people. The struggle for survival in the harsh conditions of Siberia in the first year, when a third of the village goes to the graves in the fight against hunger and cold, is repeated from year to year with each new batch of exiles who are not adapted to the climate of these places. The commandant takes it almost as a given, because he cannot help the people who were sent to die, but he never refers to the artist Ikonnikov, Dr. Leib, Zuleikha with his son Yusuf and other charges as "camp dust". The antipode of the commandant, Vasily Gorelov, is a low, vile soul, an informant, who, with anger and threats, has forced almost the entire village to write denunciations to each other. His clash at the club with Ikonnikov betrays a cruel criminal in him, serving the authorities obsequiously, without pressure, as long as he depends on her, but is ready to substitute, denigrate, torture spiritually and physically anyone who gets in his way, including the commandant. Ignatov despises this petty little soul, doing everything stealthily, and from time to time Kuznets, who comes to Semruk with an inspection, uses the services of an unscrupulous person, a traitor, as a careerist of a higher flight should be.

The outbreak of war at first does not change the life of the exiles, they are not subject to appeal as probable defectors, potential fascist henchmen, eager to avenge deprivation of rights and normal life. However, people who now hear in the Kuznets reports not only the words "five-year plan", "plan", but also the names of cities captured by the Nazis, learning about the blockade of Leningrad, feel the curtain open, separating the settlers from the whole country. The war goes far, but the inhabitants of Semruk see its echoes both in new decrees and in the appearance of new people, for example, Crimean Greeks and Tatars, deported from their homeland in the spring of 1942 - "to avoid". This term, repeated many times in the novel, expresses the state's distrust of people when it was easier to destroy them, rot them in camps, than to believe them, and let them work for the good of the country. Nevertheless, this year's war gives parts of the exiles and a certain exemption - subpoenas to the front are "trustworthy", exemption from the stigma of "exiles", a passport, that is, the opportunity to start a new life if you show yourself a good fighter and survive. So, Ikonnikov goes to war as a volunteer, ready to serve the country that rejected him, unlike Gorelov, who cannot escape the agenda, having conveniently settled in Semruk with the permission of Kuznets.

G. Yakhina often shows that "their own people", both before and during the war, are people parasitizing people, "consumables", and "strangers", "enemies" are people who preserve the nobleness of the soul, mediocrity and humanity. This idea becomes the main one in the image of post-war events: Gorelov's grip and servility played into his hands at the front. After serving time in the wagon train as a supply man, without having been in any battle, he almost immediately replaced the commandant of the village of Ignatov. The polished boots of Lieutenant Gorelov, resembling the boots of a leader, confidently tread on the tunic of an aged commandant, and the crutch that a newly arrived free man knocks from Ignatov's hands is a symbol of the weakness of humanity against the impudence of a former criminal, who has become a security officer and who lives according to the Cheka's rule: "Push the falling one!"

The war in the novel opens up new possibilities not only for disenfranchised settlers, but also for those who govern them. If in the story "Rifle" Maya solved the issue of saving or killing a young German, then in the novel "Zuleikha Opens Her Eyes" we are talking about a choice between the prosperity of one person and the death of many. War really does write off a lot and opens up many doors. So the special officer Zinovy Kuznets abruptly went uphill, became a lieutenant, but this is not enough for him: "War. The time now, Vanya, is such a hectic one, it rings in my ears. The heads are flying. And the stars fly ... smart people to the cripple ... Time is such that everything is possible, you know, everything!" (Yakhina, 2018, p. 460). The refrain mentions in the chapter the mighty palm of Kuznets, the "friend" and chief of the commandant, who lies on the scruff of Ivan. During the conversation, she gradually turns into an iron claw, squeezing Ignatov's neck more and more. This is the hand of power, coercion, at first light, and then more and more heavy, strangling a person forced to obey subordination and duty.

In conditions of almost intolerable, not presuming doubts about the logic of camp life, wartime, the commandant of the village must make a choice, show (in the terminology of Stalin's time) consciousness or myopia. G. Yakhina shows how moral, genuine confronts Ivan's soul with fears for his future. For Ignatov, 
settlers are people, for Kuznets - pawns, consumables. Ignatov does not strive for stars on uniform because they mean nothing on the Hangar and give nothing to the village, for Kuznets a new title - a new level of power, wealth, freedom from all prohibitions. The commandant should almost as quickly as a Maya nurse decide who is "his" for him and who is "stranger". The choice made by the hero logically follows from the principles by which he was always guided - he was a man, he remained. The commandant will never cause humiliation, the death of those who are not guilty of anything. Where Gorelov would not doubt for a moment what to do, Ignatov behaves with dignity and morality, which was a feat in the conditions of life of the 40s of the XX century. It is no coincidence that the following "big article in Pravda" about the pro-fascist conspiracy uncovered in the village of Pit town on the Angara. As a result of this rather high-profile case" (Yakhina, 2018 , p. 463), several dozen settlers from the neighbouring village of Semruk were shot and sent to camps for twenty-five years, the commandant of which turned out to be more accommodating, having long understood the trends of the time and the conditions of their own prosperity.

Time after time, Ignatov manifests himself as an indifferent person, goes for forgery, saving the son of Zuleikha. Even if Ivan understands some justice of Kuznets's words (for example, about the impending death from frost of the Crimean exiles, which could be expended), he still can't make a deal with the authorities, which reacts to this harshly, depriving the hero of his position, dismissing the ranks according to the article, since people with principles, as Colonel Kuznets already says, are not needed in the state security organs.

Thus, the war in the works of $G$. Yakhina is diverse. Based on the traditions of military prose, the writer poses her heroes with the choice to "live [including good, ideologically correct - approx. auth.] or to remain a man" (Bykov, 1987, p. 36). Each hero solves this dilemma in his own way. Someone immediately tries to escape, to achieve prosperity at all costs, someone cannot afford to live on at the expense of another, to show indifference to people - in battle, in the rear, in camp conditions. The choice between "friends" and "strangers" takes place in the soul of a person, and it does not always coincide with the traditional, logical one, sometimes this division is erased in principle.

To give a helping hand, to support in trouble, and not to trample a person for his own benefit or survival - this is the idea that, thanks to the works of Guzel Yakhina about the war and the camps, becomes an equal component in the content of the concept of "war".

\section{CONCLUSION}

Summing up the study, it must be emphasized that the concept of "war" in Russian literature of the XX century and at the turn of the XX - XXI centuries. deepens in its content and comprehended by the authors from a common worldview, fitting into the broad socio-historical and moral-ethical context of the search for the ideal world order and ways to achieve it. The preservation of national and universal values is the main idea that allows us to reveal the concept of "war" in the multifaceted nature of its problems, which still continues to be an open system. Representing the tragedy of war, writers of different generations turn to the artistic study of a man whose fate is somehow affected by the war. The extreme nature of the war itself, the psychology of man at war, the situation of moral choice, "one's own" and "another's" are problems that inevitably arise before the authors of works about the war and which, apparently, will be relevant for a long time, since overcoming confrontation is one of the main goals of human society, and this goal should be achieved through peace, not war.

\section{REFERENCE LIST}

Babenko, N.G. (2004). The Verbal Expression of the Semantic Opposition "One's - Another's" in The Stories of Yuri Buida. At the crossroads of cultures: Russians in the Baltic region. Kaliningrad, Vol. 7 (1.1). P. 204-213.

Baskakova, L.V. (2009). Concept of "Beauty". [Electr. resource] The conceptosphere of A. P. Chekhov. Rostov-on-Don, 368 p. URL: http://www.iprbookshop.ru/46984.html (date of the address: 15.12.2019).

Buida, Yu. (2015). Prussian Bride. Moscow, 704 p.

Bykov, V.V. (1987). In The Fog. Friendship of Peoples, No. 4. P. 3-64.

Fomenko, Yu.V. (2004). What Is Behind the Term "Concept"? Bulletin of Omsk University, No. 4 P. 113-116.

Gavrilova, M.V. (2010). Archaic Metaphor in The Structure of the Concepts of "Life" and "Death" in the Story of Yu. Buida "Prussian Bride" (Mythological and Linguistic Aspects). Proceedings of the VIII Int. 
scientific conf. "Innovations in Science and Education - 2010", dedicated to the 80th anniversary of the university: in 3 parts. Kaliningrad, Vol. 3. P. 206-208.

Evdokimova, O.K., Lyapaeva, L.V., Fedyay, S.V. (2018). Concept of "Home": Creative Interpretation in Centuries (M. Lermontov, M. Tsvetaeva, G. Aigi). Bulletin of the Chuvash State Pedagogical University named after I.Y. Yakovlev. No. 2 (98). P. 78-84.

Ivanova, I.K. (2016). History of Modernity: Yu. Buida and G. Grass. Ashmarin readings. Proceedings of the X Int. scientific and practical. conf. Cheboksary. P. 55-56.

Khvatov, A.I. (1978). The art world of Sholokhov. Moscow, 477 p.

Khusainova A. Kh. (2015). Free Choice Existence and "Laboratory-Artistic Experiment" of War Events in the Artistic Creative Work: Jean-Paul Sartre, of France, and Vasil Bykov, of Belarus. Bulletin of Kostroma State University named after N.A. Nekrasov. Vol. 21. № 5. C. 91-95.

Lavrenev, B.A. (1982). Collected Works: 6 vols. Moscow, Vol. 1, 150 p.

Likhachev, D.S. (1997). Conceptosphere of the Russian Language. Russian literature: Anthology. Moscow. P. 28-37.

Obzhogina, N.Yu. (2007). National Characters in the Novel by H. James "A Bundle of letters". Collection of scientific papers of young scientists and specialists. Cheboksary. P. 88-91.

Romanova, T.N., Fedorova, N.A. (2017). Proverbs with Component «Bread» the Russian, Ukrainian and Chuvash: Lingvoculturological Aspect. National languages and literature in a multicultural setting. Vol. 2. Cheboksary. P. 124-128.

Sarbash, L.N. (2012). Image of Life and Beliefs of the Volga Peoples in Russian Literature and Journalism of the XIX Century. Cheboksary, $402 \mathrm{p}$.

Sartre, J.-P. (1990). Existentialism Is Humanism. Twilight of the Gods. Moscow. P. 319-344.

Sholokhov, M.A. (1986). Collected Works: in 8 vols. Moscow, Vol. 7, 560 p.

Skorospelova, E.B. (2003). Russian Prose of the Twentieth Century: from A. Bely ("Petersburg") to B. Pasternak ("Doctor Zhivago"). Moscow, 420 p.

Spivak M. (2004). "German Past, Russian Present": East Prussian Text by Yuri Buida. At the crossroads of cultures: Russians in the Baltic region. Kaliningrad. Vol. 7 (1). P. 214-230.

Sukhikh, I.N. (2013). Russian Canon. Books of the 20th century. Moscow, 864 p.

Yakhina, G.Sh. (2015). The Rifle. October, No 5. P. 73-80.

Yakhina, G.Sh. (2018). Zuleikha Opens Her Eyes. Moscow. 508 p. 